\title{
Orai1 calcium channels in the vasculature
}

\author{
David J Beech
}

Received: 23 January 2012 /Revised: 21 February 2012 / Accepted: 21 February 2012 /Published online: 9 March 2012

(C) The Author(s) 2012. This article is published with open access at Springerlink.com

\begin{abstract}
Orail was discovered in $\mathrm{T}$ cells as a calciumselective channel that is activated by store depletion. Recent studies suggest that it is expressed and functionally important also in blood vessels, not only because haematopoietic cells can incorporate in the vascular wall but also because Orail is expressed and functional in vascular smooth muscle cells and endothelial cells. This article summarises the arising observations in this new area of vascular research and debates underlying issues and challenges for future investigations. The primary focus is on vascular smooth muscle cells and endothelial cells. Specific topics include Orai1 expression; Orail roles in store-operated calcium entry and ionic currents of store-depleted cells; blockade of Orai1related signals by Synta 66 and other pharmacology; activation or regulation of Orail-related signals by physiological substances and compartments; stromal interaction molecules and the relationship of Orail to other ion channels, transporters and pumps; transient receptor potential canonical channels and their contribution to store-operated calcium entry; roles of Orail in vascular tone, remodelling, thrombus formation and inflammation; and Orai2 and Orai3. Overall, the observations suggest the existence of an additional, previously unrecognised, calcium channel of the vascular wall that is functionally important particularly in
\end{abstract}

\section{J. Beech}

Multidisciplinary Cardiovascular Research Centre,

University of Leeds,

Leeds LS2 9JT, UK

\section{J. Beech ( $\square)$}

Faculty of Biological Sciences, University of Leeds,

Garstang Building, Mount Preston Street,

Leeds LS2 9JT England, UK

e-mail: d.j.beech@leeds.ac.uk remodelling but probably also in certain vasoconstrictor contexts.

Keywords Calcium channel · Blood vessel · Vascular smooth muscle cell $\cdot$ Endothelial cell

\section{Introduction}

In 2006, seminal work identified membrane proteins that were named Orais, after the Greek keepers of Heaven's gate $[20,32,33,75,76,97,108,109]$. An alternative name is CRACM but this is less commonly used. The proteins emerged through a study of severe combined immune deficiency (SCID), which is caused by a defect in $\mathrm{Ca}^{2+}$ entry of $\mathrm{T}$ cells [32]. A mutation in the Orail gene underlies this defect [33].

In predicted structure, the Orais resemble members of the extensively studied tetraspanin proteins. The Orais do not resemble other known ion pore-forming subunits of ion channels, although similarity to the regulatory (non-poreforming) $\gamma$-subunit of voltage-gated $\mathrm{Ca}^{2+}$ channels has been suggested [99]. Nevertheless, several studies now indicate that Orais cluster together to form a $\mathrm{Ca}^{2+}$ selectivity filter and thus can be considered to be bona fide $\mathrm{Ca}^{2+}$ channels $[108,109]$. Other tetraspanins or tetraspanin-like proteins are not known to form $\mathrm{Ca}^{2+}$ channels, although MS4A12 (a sequence homologue of CD20) is a candidate [53]. At the present time, there are no crystal structures for Orais, but they are suggested to have four membrane spanning segments, two extracellular loops and intracellular amino and carboxy termini $[66,109]$. A pear-drop structure about $15 \mathrm{~nm}$ in height and $9.5 \mathrm{~nm}$ in width is indicated by electron microscopy [66]. Residency in the plasma membrane occurs but localisation to other compartments is not excluded. The 
Orais have molecular masses of about $30 \mathrm{kDa}$ and these may be substantially increased by glycosylation.

Against the immunological backdrop of Orail's discovery, it was initially surprising that Orail is widely expressed but many studies now suggest expression of Orail not only in cells of the haematopoietic lineage [32] but also in other cell types that include vascular smooth muscle and endothelial cells (see below). The observations have started to provide important new insight into the $\mathrm{Ca}^{2+}$-handling capabilities of these cell types and shed light on the enigmatic process of store-operated $\mathrm{Ca}^{2+}$ entry (SOCE), which was first suggested in vascular smooth muscle 31 years ago [21]. Orai2 and Orai3 may also be relevant to blood vessels but available information on them is limited (see below).

This review summarises and debates evidence that Orais are important in blood vessels, with particular focus on two primary cell types of the vascular wall: vascular smooth muscle cells and endothelial cells in either their quiescent phenotypes or proliferating and migrating phenotypes. The quiescent phenotypes are especially relevant to the control of contractile tone and its regulation by endothelial factors, impacting on whole body phenomena such as peripheral resistance and tissue perfusion. The proliferating and migrating phenotypes are especially relevant to vascular development and the remodelling events of physiology and pathology that include neointimal hyperplasia, angiogenesis and endothelial repair.

\section{Expression of Orai1 mRNA and protein}

Most of the RT-PCR, western blotting and immunocytochemical evidence for expression of Orail in vascular cells has arisen from studies of cultured vascular smooth muscle cells, which are migrating and proliferating but not contractile. Orail mRNA and protein were demonstrated in this type of cell derived from human aorta or saphenous vein $[8$, $13,59]$, rat aorta $[15,77]$, rat coronary artery [29] or mouse pulmonary artery [70]. Orail was also detected in the A10 cell line [24], which is a model system for proliferating vascular smooth muscle cells. Orail protein was found to be almost undetectable in human aorta homogenate [13] or freshly isolated rat aorta vascular smooth muscle cells [77]. Orail protein was, however, detected in pig coronary artery [31] and rat carotid artery [107], and weak staining was reported in the smooth muscle cells of arterial sections [15, 107]. Orail protein was detected in rat coronary artery that had been organ-cultured for $48 \mathrm{~h}$ [29]. In vivo injury of arteries by physical or metabolic insult enabled clear detection of endogenous Orail in vascular smooth muscle cells of intact arteries [15, 31, 107]. Furthermore, a 24-h treatment of cultured vascular smooth muscle cells with plateletderived growth factor (PDGF) led to enhanced Orail protein expression [72]. Therefore, the available evidence suggests relatively low Orail expression in native contractile vascular smooth muscle cells and higher expression in proliferating and migrating vascular smooth muscle cells, whether the phenotype is induced in vitro or in vivo. There is less RT-PCR or biochemical evidence for expression of Orai1 in endothelial cells. Nevertheless, Orail mRNA and protein were detected in human umbilical vein endothelial cells (HUVECs) [1, 57, 88], the HUVEC adenocarcinoma EA. hy926 cell line [6], human lung microvessel endothelial cells [88], rat pulmonary microvascular endothelial cells [81] and immortalised mouse lung endothelial cells [88]. Orail mRNA was also detected in endothelial colonyforming cells [80].

\section{Positive role of Orai1 in SOCE}

A common experimental protocol applied to isolated cells is the short-term depletion of intracellular $\mathrm{Ca}^{2+}$ stores in the absence of extracellular $\mathrm{Ca}^{2+}$, for example through application of physiological agonists that cause $\mathrm{IP}_{3}$-induced $\mathrm{Ca}^{2+}$ release or application of pharmacological substances that inhibit sarcoplasmic/endoplasmic reticulum $\mathrm{Ca}^{2+}$ ATPase (SERCA, the pump mechanism that normally loads $\mathrm{Ca}^{2+}$ into the stores). Extracellular $\mathrm{Ca}^{2+}$ is then added back to observe $\mathrm{Ca}^{2+}$ entry, which is detected by an intracellular $\mathrm{Ca}^{2+}$ indicator. The detected rise in intracellular $\mathrm{Ca}^{2+}$ is often called the $\mathrm{Ca}^{2+}$ add-back response. The response is considerably larger in cells that have undergone store depletion, and it is primarily this observation that has led to the suggestion that store depletion triggers the opening or insertion of additional $\mathrm{Ca}^{2+}$ entry channels in the plasma membrane. The additional $\mathrm{Ca}^{2+}$ entry is often referred to as SOCE (or capacitative $\mathrm{Ca}^{2+}$ entry) and the channels as store-operated channels (SOCs) [95]. The experimental protocol is simple and the SOCE is striking but the complexities of the underlying biology are considerable, not least because such store depletion evokes radical changes in intracellular $\mathrm{Ca}^{2+}$ handling and store depletion itself is one of the classical triggers for endoplasmic reticulum (ER) stress and the associated unfolded protein response [27]. Nevertheless, studies of SOCE have yielded critical understanding of mechanisms controlling $\mathrm{Ca}^{2+}$ in a wide variety of cell types. Orail is an important element.

In cultured vascular smooth muscle cells and endothelial cells, there is SOCE. Inhibition of Orail expression has been found to reduce this SOCE $[1,8,29,57,59,64,70$, $77,103]$. The degree of reduction has varied from study to study but most reports agree that Orail plays a positive role in SOCE of these vascular cells. The studies have depended on the use of short-interfering (si) RNA [48] to suppress Orail expression and thus relied on the specificity of this 
manipulation. Nevertheless, a range of different Orail siRNAs have been used and the role of Orail has been confirmed by expression of a dominant-negative mutant of Orai1 [57, 59, 64]. Furthermore, over-expression of wild-type Orail has been shown to rescue SOCE after Orail knock-down by siRNA [59]. There have been suggestions of a critical (i.e. essential) role for Orai1 in SOCE. Evidence for such suggestions comes from studies of $T$ cells from SCID patients or mice carrying genetic disruption of the Orail gene, but even in these studies residual SOCE can be observed [96]. Studies of vascular smooth muscle cells and endothelial cells in the complete absence of Orail have yet to be reported. Studies of cells from gene-disrupted Orai1-/- mice are complicated by immune deficiency and perinatal lethality [47].

A study of immortalised mouse endothelial cells found no effect on SOCE of Orail siRNA or over-expression of wild-type Orai1 or dominant-negative mutant Orai1 [88]. In human lung microvessel endothelial cells, Orai1 siRNA appeared to reduce the initial peak SOCE but a statistically significant effect was not identified [88]. The investigators suggested that, although Orail is expressed, it does not contribute to SOCE in these microvascular-derived endothelial cell types.

\section{Positive roles of Orai1 in ionic current of store-depleted cells}

If SOCE does indeed result from net inward movement of $\mathrm{Ca}^{2+}$ across the plasma membrane, there must be an inward ionic current and it may be possible to detect it by whole-cell patch-clamp electrophysiology. Patchclamp also has the ability to control the membrane potential and so minimise changes in membrane potential that complicate interpretation of results from intracellular $\mathrm{Ca}^{2+}$ indicator studies. Furthermore, the intracellular dialysis of cells with $\mathrm{Ca}^{2+}$ buffers, delivered by the patchclamp pipette, can avoid or minimise intracellular $\mathrm{Ca}^{2+}$ rises that stimulate ion channels.

Patch-clamp studies of blood cells have, for many years, consistently revealed a distinctive inward ionic current under conditions that cause store depletion [75]. The current is referred to as calcium-release-activated $\mathrm{Ca}^{2+}$ (CRAC) current, or I-CRAC, and is quite well established as an electrophysiological correlate of SOCE. It is characterised by its $\mathrm{Ca}^{2+}$ selectivity, inward rectification and very small amplitude (a few picoamperes). Single channel currents are calculated to be well below the resolving power of patch-clamp technology. Orail clearly plays a major role in I-CRAC and is considered to arrange as a tetramer to form the ion pore of the underlying $\mathrm{Ca}^{2+}$ channels $[66,109]$. It is important to note that the experimental conditions for recording I-CRAC are largely standardised and non-physiological [1, 14].
Some of these conditions have been necessary to distinguish the current from other signals. Features of the conditions include the high concentration of extracellular $\mathrm{Ca}^{2+}$ (usually 10 or $20 \mathrm{mM}$ ) and hyper-tonicity of the extracellular medium. A $\mathrm{Na}^{+}$-mediated 'I-CRAC' is often recorded in the complete absence of extracellular $\mathrm{Ca}^{2+}$ (divalent cation free, DVF, medium). Another common condition is a high concentration of $\mathrm{Ca}^{2+}$ buffer in the intracellular (patch pipette) solution (e.g. $20 \mathrm{mM}$ BAPTA). The buffer serves the purposes of depleting the stores and suppressing cytosolic $\mathrm{Ca}^{2+}$ rises but it also lowers the basal cytosolic $\mathrm{Ca}^{2+}$ concentration, indiscriminately inactivating $\mathrm{Ca}^{2+}$-dependent processes. It is less common that I-CRAC is shown to be activated by a SERCA inhibitor when intracellular $\mathrm{Ca}^{2+}$ is buffered at the physiological concentration of about $100 \mathrm{nM}$.

There has been more difficulty recording I-CRAC or I-CRAC-like signals from vascular smooth muscle cells or endothelial cells [1, 37, 40, 57, 77, 98]. All of these recordings have been made from cell lines or low passage cells after primary culture. Therefore, the cells have been in proliferating and migrating phenotypes. The first report showing an I-CRAC-like signal was based on HUVECs [1]. The current amplitude was about five times smaller than that of immune cells, which is close to the resolving power of whole-cell patch-clamp. It was most convincingly shown in DVF medium and using $20 \mathrm{mM}$ BAPTA in the patch pipette. It exhibited characteristics similar to those of the $\mathrm{Na}^{+}$'I-CRAC' of blood cells. It was diminished by Orail siRNA. Similar recordings were made from A7r5 and cultured rat aorta vascular smooth muscle cells [77, 98]. Similar reduction by Orai1 siRNA was observed [77].

Although investigation of the relationship to Orail was not shown, patch-clamp studies to seek out and determine the properties of I-CRAC were reported also in studies of EA.hy926 cells [40]. Perforated patch whole-cell recording was used in order to minimise the modification of the intracellular milieu. I-CRAC-like current was detected in response to SERCA inhibition in the presence of extracellular $10 \mathrm{mM} \mathrm{Ba}^{2+}$ and $2 \mathrm{mM} \mathrm{Ca}^{2+}$, or $0.1 \mathrm{mM} \mathrm{Ba}^{2+}$ and $10 \mathrm{mM} \mathrm{Ca}^{2+}$. The current was inwardly rectifying and small but showed a reversal potential near $-11 \mathrm{mV}$ [40]. Such a reversal potential, compared with the positive value described for I-CRAC in blood cells, led the authors to suggest that the current had less $\mathrm{Ca}^{2+}$ selectivity than I-CRAC of blood cells.

I-CRAC is not the only ionic current activated by store depletion. Various studies of proliferating or contractile vascular smooth muscle cells or endothelial cells have shown a non-selective cationic current $[12,31,60,63,64$, $79,89,94,101,103]$. The characteristics of currents vary between studies and standardised recording conditions have not been used but the current-voltage relationship $(I-V)$ 
tends to be relatively linear, the reversal potential close to or approaching $0 \mathrm{mV}$, and current observed with or without strong buffering of intracellular $\mathrm{Ca}^{2+}$. A recent report showed that Orail siRNA strongly suppressed the current in mouse aorta smooth muscle cells [103]. There is a similar current in proliferating human saphenous vein vascular smooth muscle cells [60] and it too is suppression by Orai1 siRNA [58]. The current is hard to reconcile with the properties of Orail $\mathrm{Ca}^{2+}$ channels as defined by I-CRAC. The phenomenon remains an on-going matter of investigation but, in part, it is explained by transient receptor potential (TRP) canonical channels (see below). Apparently similar non-selective cationic currents evoked by store depletion have been reported in blood cells and skeletal muscle [86, 87]. Studies of EA.hy 926 cells have emphasised the complication that can arise from $\mathrm{Na}^{+}-\mathrm{Ca}^{2+}$ exchanger current [40] but this is not the explanation for the non-selective cationic current.

\section{Blockade of Orai1-related signals by Synta 66 and other pharmacology}

An intriguing pharmacological agent in relation to Orai1 $\mathrm{Ca}^{2+}$ channels, SOCE and I-CRAC is the chemical that is referred to as Synta 66 (3-fluoropyridine-4-carboxylic acid (2',5'-dimethoxybiphenyl-4-yl)amide). In addition to patent information (WO 2005/009954), the effects of Synta 66 on SOCE and I-CRAC in basophilic leukaemia and Jurkat T cells have been reported $[26,71]$. Synta 66 does not affect plasma membrane $\mathrm{Ca}^{2+}$ ATPase, inward rectifier $\mathrm{K}^{+}$current, hippocampal synaptic transmission, or radio-ligand binding to a range of receptors and ion channels including the L-type $\mathrm{Ca}^{2+}$ channel $[26,71]$.

Synta 66 is also an inhibitor of SOCE in proliferating vascular smooth muscle cells and endothelial cells [57, 59]. Strikingly, the $\mathrm{IC}_{50}$ is $\sim 25 \mathrm{nM}$ which is about two orders of magnitude better than for blood cells [57, 59]. The speed of block is relatively rapid (occurring in less than $10 \mathrm{~s}$ ). Selectivity of Synta 66 was also suggested because there was no effect of $5 \mu \mathrm{M}$ Synta 66 on $\mathrm{Ca}^{2+}$ release evoked by ATP or growth factors $[57,59]$. There was no effect on $\mathrm{Ca}^{2+}$ entry through transient receptor potential canonical (TRPC1, 5, 6) or vanilloid (TRPV4) channels, each activated without store depletion. There was also no effect on contraction of aorta evoked by an $\alpha_{1}$-adrenoceptor agonist, suggesting no effect of Synta 66 on the array of systems underlying this complex contractile phenomenon [59]. There was no effect on cell viability [57]. Synta 66 appears, therefore, to be an easy-touse, selective and potent inhibitor of SOCE. It is not currently available from a commercial supplier but may be obtained as a gift from a pharmaceutical company or synthesised relatively easily by a medicinal chemist.
The mechanism of action of Synta 66 on SOCE is unknown. It may act as an ion pore blocker of Orail $\mathrm{Ca}^{2+}$ channels, perhaps by binding directly to Orail. However, evidence to support such a hypothesis is not reported. Indeed, the common roles of Orail in SOCE of vascular smooth muscle cells, endothelial cells and blood cells, set against the differential potencies of Synta 66 in these cell types (as text above), argue against Orail as the target protein. Nevertheless, if Orail is not the target protein, we do not yet have another clear candidate as the target. It is conceivable that it acts in some way to modify the coupling between depleted stores and Orail channels but this is not exhibited as an effect on the clustering of the store $\mathrm{Ca}^{2+}$ sensor [59]. It is also not exhibited as inhibition of nonselective cationic current evoked by store depletion [59].

Other inhibitors of vascular SOCE include 2aminoethoxydiphenyl borate (2-APB), 4-methyl-4'-[3,5-bis (trifluoromethyl)-1H-pyrazol-1-yl]-1,2,3-thiadiazole-5-carboxanilide (BTP-2, Pyr2, or YM-58483) and lanthanides $[35,67,77,80]$. These agents are also commonly described as TRPC channel inhibitors. Additional inhibitors of SOCE are listed by Flemming et al. [35] or include diethylstilbestrol [105], non-steroidal anti-inflammatory drugs [67], and 5-nitro-2-(3-phenylpropylamino)-benzoic acid [37]. It is not clear if any of these agents act directly as channel blockers and there is evidence that some of the agents, such as nonsteroidal anti-inflammatory drugs, act indirectly [67].

The greater potency of Synta 66 on SOCE of vascular smooth muscle and endothelial cells (compared with blood cells) suggests a difference in the molecular mechanism of SOCE in these cells, even though the SOCE in all cases shows partial or strong dependence on Orail. Different sensitivity to 2-APB [77] adds weight to this suggestion. Weaker $\mathrm{Ca}^{2+}$ selectivity of I-CRAC in endothelial cells has also been suggested to indicate a different molecular basis [40]. The identity of such distinction is not yet reported.

\section{Activation or regulation of Orai1-related signals by physiological substances and compartments}

The studies described above refer to $\mathrm{Ca}^{2+}$ entry evoked by non-physiological stimuli. This is not to infer that they lack physiological relevance but it is necessary to consider if or when physiological stimuli can activate them. This is especially important because store depletion is a signal that leads to cell apoptosis and because physiological agonists can evoke $\mathrm{Ca}^{2+}$ release without causing significant store depletion, as demonstrated, for example, by simultaneous measurements of cytosolic and $\mathrm{ER} \mathrm{Ca}^{2+}$ in endothelial cell lines $[40,65]$. However, many investigators have applied physiological agonists to cells in the absence of extracellular $\mathrm{Ca}^{2+}$ and then used the $\mathrm{Ca}^{2+}$ add-back protocol to observe $\mathrm{Ca}^{2+}$ 
entry. While this protocol reduces confusion between $\mathrm{Ca}^{2+}$ release and $\mathrm{Ca}^{2+}$ entry, it is weakened by being a store depletion protocol (because the stores cannot refill after the $\mathrm{Ca}^{2+}$ release event). The experimental difficulty involved in avoiding inadvertent store depletion has been emphasised [40]. Consequently, there is only limited information about which physiological agonists activate $\mathrm{Ca}^{2+}$ entry that depends on Orail in the continuous presence of extracellular $\mathrm{Ca}^{2+}$ and without store depletion. Two substances that activate the channels in this situation are the important growth factors PDGF and vascular endothelial growth factor (VEGF) $[57,59]$. ATP activates Synta 66-sensitive $\mathrm{Ca}^{2+}$ entry in the continuous presence of extracellular $\mathrm{Ca}^{2+}$ but it was not reported if this effect was inhibited by Orail siRNA [59]. Strikingly, $\mathrm{Ca}^{2+}$ entry stimulated by lysophosphatidylcholine $(0.3 \mu \mathrm{M})$ was suppressed by Orail siRNA even though the lysophosphatidylcholine did not evoke $\mathrm{Ca}^{2+}$ release, suggesting $\mathrm{Ca}^{2+}$-release-independent activation of Orail channels in vascular smooth muscle cells [29].

Intriguing stimulation of SOCE-like $\mathrm{Ca}^{2+}$ entry by sphingosine-1-phosphate has been described in vascular smooth muscle cells [50]. While sphingosine-1-phosphate evoked $\mathrm{Ca}^{2+}$ release via $\mathrm{G}$ protein-coupled receptors, the SOCE-like signal occurred independently of sphingosine-1phosphate receptors and was mimicked by intracellular sphingosine-1-phosphate [50]. The SOCE-like signal was not, however, shown to be Orail-dependent.

Localisation of Orail to membrane density fractions containing caveolin-1 was described in studies of pulmonary microvascular endothelial cells, suggesting compartmentalisation of Orail-dependent $\mathrm{Ca}^{2+}$ signalling [81]. The fractions also contained the $\mathrm{Ca}^{2+}$-regulated adenylyl cyclase 6 . A submembrane compartment for regulation of filamin A by $\mathrm{Ca}^{2+}$ and cyclic AMP was suggested to play a role in the control of endothelial cell shape [81].

\section{Stromal interaction molecules (STIMs) and the relationship of Orail to other ion channels, transporters and pumps}

A year before the discovery of Orail came the discovery of the relevance of stromal interaction molecules 1 and 2 (STIM1 and STIM2) to SOCE [20, 78]. STIMs are singlepass membrane-spanning proteins that are larger than Orais (STIM1 has a predicted mass of $75 \mathrm{kDa}$ ). Unlike Orais, STIMs were initially identified independently of the $\mathrm{Ca}^{2+}$ signalling field as glycosylated phosphoproteins located to the cell surface. Although subsequent studies confirmed STIM1 localisation in the plasma membrane, its relevance to SOCE is now most commonly described in terms of STIM1 as a protein of the ER membrane [20]. Prior to store depletion, STIM1 is thought to directly bind the microtubule-plus-endtracking protein EB1, forming comet-like accumulations [44].
STIM1 is considered to be the primary sensor of the $\mathrm{Ca}^{2+}$ content of the ER (or sarcoplasmic reticulum), detecting store depletion and relaying this information to Orail channels in the surface membrane through a complex process of conformational change, redistribution, clustering and physical association with Orail that clusters Orail proteins and activates them to enable $\mathrm{Ca}^{2+}$ entry [20]. STIM2 is also thought to play such a role but with a different $\mathrm{Ca}^{2+}$ sensitivity [20].

STIM1 and STIM2 are expressed in vascular smooth muscle cells and endothelial cells. Knock-down of the expression of either type of STIM suppresses SOCE, with STIM1 knock-down usually showing the greater effect $[60,62]$. Detailed studies on other cell types have demonstrated Orai1 and STIM1 interaction [76, 104]. Less detailed studies have provided data in support of the interaction and co-localisation of endogenous Orai1 and STIM1 in vascular smooth muscle cells $[17,70]$. Investigation of endogenous STIM1 has also revealed constitutive localisation to the plasma membrane and surface exposure of the amino terminus in vascular smooth muscle cells [60]. This surface STIM1 localisation is not altered by store depletion [60]. Although ER localisation of STIM1 has been suggested in vascular smooth muscle cells [92], it was not definitely identified as ER STIM1 and extensive investigation of this STIM1 has yet to be reported. A challenge with studies of STIM1 localisation is that protein tags attached to the STIM1 molecule prevent its surface localisation, tending to favour ER localisation of the STIM1 [49].

STIM1 does not only interact with Orail channels, it also binds ion channels that include TRPC1 and the voltagegated $\mathrm{Ca}^{2+}$ channel subunit $\mathrm{Ca}_{\mathrm{V}} 1.2[98,106]$. Biochemical interaction of endogenous STIM1 and TRPC1 has been demonstrated in vascular smooth muscle cells, but there is only partial co-localisation of the proteins, suggesting that they share a function but also have discrete functions [60]. Studies in over-expression systems have suggested that STIM1 activates TRPC1 channels following store depletion [106]. In endothelial cells, store depletion evoked forward trafficking of TRPC1 and TRPV4 to the surface membrane and this effect was partially inhibited by STIM1 siRNA [63, 64]. Studies in the A7r5 vascular smooth muscle cell line have suggested that STIM1 interaction inhibits $\mathrm{Ca}_{\mathrm{V}} 1.2$, leading to suppression of voltage-dependent $\mathrm{Ca}^{2+}$ entry in store-depleted cells and a reciprocal relationship with SOCE [98]. Clustering of STIM1 and Orail with $\mathrm{Na}^{+}-\mathrm{Ca}^{2+}$ exchanger, plasma membrane $\mathrm{Ca}^{2+}$ ATPase and SERCA is suggested from studies of other cell types, indicating that STIM1 has a broad coordinating role for $\mathrm{Ca}^{2+}$ transport mechanisms and emphasising that its function is not restricted to Orail interaction [54]. Specifically in proliferating vascular smooth muscle cells, co-localisation of Orail and $\mathrm{Na}^{+}-\mathrm{Ca}^{2+}$ exchanger (NCX1) was observed and Orail siRNA suppressed NCX1 expression as well as Orai1 expression [8]. Plasma membrane 
$\mathrm{Ca}^{2+}$ ATPase (PMCA1) expression was also suppressed. $\mathrm{Na}^{+}-$ $\mathrm{Ca}^{2+}$ exchange did not, however, influence SOCE [8]. SERCA2a, but not SERCA2b, expression was found to inhibit interaction between Orail and STIM1 [17]. Because SERCA2a was down-regulated when vascular smooth muscle cells switched to the proliferating phenotype, it was suggested that loss of this inhibitory effect of SERCA2a may contribute to the explanation for the large SOCE in proliferating vascular smooth muscle cells and the associated translocation of nuclear factor of activated T cells to the nucleus [17].

\section{TRPC channels and SOCE}

It is suggested by the above text that Orail $\mathrm{Ca}^{2+}$ channels contribute to SOCE in vascular smooth muscle cells and endothelial cells. There are, however, also reports suggesting that TRPC channels contribute to SOCE in these cells $[19,36,55,60,63,64,69,82,88-91,93,100,101]$. Although crystal structures are lacking for Orai and TRPC channels, there are clear suggestions that Orai and TRPC proteins are structurally unrelated. Moreover, the Orais mostly generate small $\mathrm{Ca}^{2+}$-selective and inwardly rectifying channels, whereas TRPC channels generate larger mixed cationic $\mathrm{Ca}^{2+}$ - and $\mathrm{Na}^{+}$-permeable channels with complex rectification that includes substantial outward current. These two channel types are unlikely to participate in generating a common ion pore (i.e. they are almost certainly distinct ion channels). Furthermore, while Orail channels have mostly been associated with activation by store depletion, there is plenty of evidence that TRPC channels do not require store depletion in order to be activated and may often be activated even without concomitant $\mathrm{Ca}^{2+}$ release $[2,3,10,102]$. The TRPC channels are not addressed in detail here, but a brief discussion of the relation to SOCE is included because the suggestion that they also contribute to SOCE is controversial, because the physiological significance of SOCE should be addressed, and because there is indication of an intimate relationship between Orai and TRPC channels, which remains poorly understood.

It may be that both Orail and TRPC channels contribute to vascular SOCE. This would explain why some studies show partial suppression of SOCE by Orail or TRPC siRNA [59, 60]. Different (apparently conflicting) results from different research groups $[1,46,64,88,91]$ may be explained by variable relative contributions of Orail and TRPC depending on the exact type of cell, the condition of the cells, the culture medium, the substrate, the precise details of the experimental protocol, etc. Shared contribution to SOCE would be consistent with the substantial evidence that both types of channel interact with STIM1 $[76,106]$ and that STIM1 redistribution in response to store depletion has major implications for a range of $\mathrm{Ca}^{2+}$ transport proteins
[54]. One study of cultured vascular smooth muscle cells suggested that Orail determines the first (transient) phase of SOCE, and TRPC1 the sustained SOCE $[69,70]$. A study of EA.hy926 cells suggested a time-independent and distinct TRPC3 component of SOCE that depended on phospholipase $\mathrm{C}$ activity [6]. These studies suggest two distinct channels of SOCE (Orai and TRPC), but a study of HUVECs has suggested overlap and a shared Orai-TRP channel arrangement [64].

Important in this discussion is the definition of SOCE which, in practice, is a $\mathrm{Ca}^{2+}$ entry phenomenon observed under non-physiological conditions (see above). From a biological perspective, however, many investigators have been using SOCE as a means to understand the physiological mechanism by which stores refill following $\mathrm{IP}_{3}$-evoked $\mathrm{Ca}^{2+}$ release. The refilling process is expected to be triggered by the SOCE protocol but the protocol also has other consequences that probably do not occur, or are less prominent, when a physiological agonist evokes $\mathrm{Ca}^{2+}$ release under physiological conditions at a physiological concentration. One of these consequences is ER stress. Given the emerging evidence of TRPC activation by stress factors [3, $10,28,68]$, it can be anticipated that TRPC activity may be increased as a result of the SOCE (ER stress?) protocol. Potentially, dependence of SOCE on $\mathrm{Ca}^{2+}$-independent phospholipase $A_{2}[29,85,103]$ reflects such a stress relationship because activation of this phospholipase is one of the factors involved in TRPC channel activation [4], Orai1 activation [29] and the ER stress response [56].

Another method for investigating the physiological refilling process has been the I-CRAC protocol. In many studies, however, this too is non-physiological (see above). Furthermore, the protocol is designed to isolate and highlight ICRAC. It is quite possible that the intricate $\mathrm{Ca}^{2+}$ and $\mathrm{Ca}^{2+}$ sensor dependencies of TRPC channels [16, 51, 74, 82, 83] lead them to be suppressed or otherwise modified by the ICRAC recording protocol, which may explain why there has been little or no resemblance of I-CRAC to ionic currents generated by over-expressed TRPC channels. Intriguingly, however, a study of freshly isolated contractile vascular smooth muscle cells showed a relatively linear $I-V$ in I-CRAC recording conditions and strong dependence on TRPC1 [82].

In summary, it is suggested that (1) Orail and TRPC form distinct ion channels that do not heteromultimerise with each other; (2) Orail and TRPC can both contribute to the SOCE phenomenon in vascular smooth muscle cells or endothelial cells; (3) Orail and TRPC interact physically with STIM1 and interplay with other $\mathrm{Ca}^{2+}$ handling proteins such as $\mathrm{Na}^{+}-\mathrm{Ca}^{2+}$ exchanger; (4) Orail is the molecular basis of the I-CRAC $\mathrm{Ca}^{2+}$-selectivity filter and TRPCs do not contribute to it; (5) I-CRAC is not the only ionic current activated by store depletion; 
and (6) TRPCs or Orais can both be activated independently of store depletion or $\mathrm{Ca}^{2+}$ release.

Elucidation of the physiological mechanism by which stores refill following $\mathrm{IP}_{3}$-evoked $\mathrm{Ca}^{2+}$ release is one of the goals of the research. What we do know is that the $\mathrm{Ca}^{2+}$-ATPases of the stores, and especially SERCAs, are the refilling mechanism at the level of the stores and that they refill the stores using free $\mathrm{Ca}^{2+}$ from the cytosol. Therefore, in principle, any $\mathrm{Ca}^{2+}$ entry channel that contributes to the cytosolic free $\mathrm{Ca}^{2+}$ concentration near SERCA can contribute to store refilling; even $\mathrm{Na}^{+}$entry acting indirectly via $\mathrm{Na}^{+}-\mathrm{Ca}^{2+}$ exchange can contribute. There is evidence that several types of $\mathrm{Ca}^{2+}$ entry channel can contribute in this way. The fascination in the field, however, has been that there might be a particular type of $\mathrm{Ca}^{2+}$ entry channel that is particularly specialised for providing $\mathrm{Ca}^{2+}$ to SERCA and in a restricted subcellular compartment. This specialised channel would seem to be the I-CRAC channel (i.e. the Orail channel). Evidence is pointing to the conclusion that such a specialised channel is a core feature across many cell types, including vascular smooth muscle cells and endothelial cells. Indeed, the original pioneering study of store refilling in vascular smooth muscle argued for a privileged $\mathrm{Ca}^{2+}$ entry mechanism that directly fills the stores from the extracellular medium with minimal impact on the global cytosolic $\mathrm{Ca}^{2+}$ concentration [21]. Nevertheless, it does not follow that this privileged mechanism is the only $\mathrm{Ca}^{2+}$ entry mechanism providing extracellular $\mathrm{Ca}^{2+}$ for store refilling or that it is the only $\mathrm{Ca}^{2+}$ entry channel activated by store depletion. It seems unlikely that cells would have evolved dependence on a single mechanism for store refilling when store depletion is a critical event leading to apoptosis.

\section{Orai1 in vascular tone (contractile phenotype)}

After a period of depletion of $\mathrm{Ca}^{2+}$ stores in $\mathrm{Ca}^{2+}$-free extracellular medium, $\mathrm{Ca}^{2+}$ add-back was found to cause a contractile response in aorta that was larger in stroke-prone spontaneously hypertensive rats [38]. Delivery of anti-Orai1 antibody by the Chariot technique suppressed the contraction [38]. These data suggest that functional Orail channels exist in contractile vascular smooth muscle cells of the aorta. Superficially, the observation conflicts with the finding that Synta 66 had no effect on $\alpha 1$-adrenoceptor-mediated contraction of mouse aorta [59]. The Synta 66 result is, however, consistent with the study of rat aorta which showed that SOCE inhibitors were ineffective when the $\mathrm{Ca}^{2+}$ add-back response was not preceded by exposure to a SERCA inhibitor in normotensive animals [38]. Therefore, the preliminary conclusion from these studies is that SOCE is not particularly important in contractile function of physiological aorta unless there is substantial store depletion. The suggestion is reminiscent of prior studies, for example on cerebral arterioles, which have also suggested that SOCE generates an intracellular $\mathrm{Ca}^{2+}$ elevation that is not well coupled to contraction [34]. However, investigation of rat coronary artery has shown that contractions evoked by urotensin-II, the $\alpha 1$-adrenoceptor agonist phenylephrine or lysophosphatidylcholine are suppressed in arterial segments cultured for $48 \mathrm{~h}$ after Orail siRNA delivery [29]. The effects were observed in the continuous presence of extracellular $\mathrm{Ca}^{2+}$, and therefore, they suggest that Orail channels are important in physiological contractile responses of this artery. A note of caution, however, is that previous work on basilar artery suggested that SOCE had no effect on contraction of freshly isolated artery but strong effect on contraction after organ culture of the artery for $72 \mathrm{~h}$ [11, 12]. Although vessels can remain contractile after periods of culture, early remodelling events are likely to have taken place (see below). Further studies would be valuable on the relevance of Orail to contractile function in various blood vessels and in relation to endothelium-dependent vasodilatation.

\section{Orai1 in vascular remodelling (migrating and proliferating phenotypes)}

Several studies have found that expression of Orai1 mRNA and protein are up-regulated when vascular smooth muscle cells undergo their switch from the contractile to the noncontractile (migrating and proliferating) phenotype (see above). It has also been observed that SOCE is larger in proliferating vascular smooth muscle cells [41, 42] and many of the studies of SOCE and Orail have focused on vascular smooth muscle cells in culture, which causes rapid switching to the non-contractile phenotype. Moreover, inhibition of migration has been observed after Orai1 knockdown by siRNA, suggesting an important role of Orai1 in the non-contractile phenotype [59, 77]. An inhibitory effect of Orail siRNA on cell number of rat aorta vascular smooth muscle cells was reported [77], but the effect was relatively small and the number of human saphenous vein vascular smooth muscle cells was unaffected at the same 48-h time point, suggesting a preferential effect on migration [59]. In studies of human aorta vascular smooth muscle cells, there was a reduction in cell number at the later time point of $77 \mathrm{~h}$ [8]. Similarly, Synta 66 inhibited migration but not the number of vascular smooth muscle cells [59]. Further support for a role of Orail in the migrating phenotype came from the finding that Orail siRNA markedly inhibited the sustained elevation of intracellular $\mathrm{Ca}^{2+}$ evoked by PDGF in the continuous presence of extracellular $\mathrm{Ca}^{2+}$ [59]; this finding is important because PDGF is the primary growth factor driving smooth muscle cell recruitment during vascular development and pathological remodelling [52]. In vivo studies have found that Orail knock-down strongly reduces 
neointimal formation in carotid artery [46, 107], similar to the effect of STIM1 knock-down [7, 45]. Similarly, STIM1 knock-down suppresses vascular smooth muscle cell migration in vitro [60]. Collectively, these findings suggest that Orail channels and SOCE play key positive roles in enabling efficient vascular smooth muscle cell remodelling, working with a range of other ion channels that include TRPC1 and $\mathrm{K}_{\mathrm{V}} 1.3$ potassium channel $[9,23,25,55]$.

Endothelial cells also remodel using a phenotype that displays migrating and proliferating properties. Knockdown of Orail by siRNA inhibits the migration [57] and proliferation [1] of HUVECs. It also markedly inhibits the sustained elevation of intracellular $\mathrm{Ca}^{2+}$ evoked by VEGF [57], the primary growth factor driving endothelial cell migration and endothelial remodelling events such as angiogenesis [73]. In vitro tube formation, which mimics features of angiogenesis, was inhibited by Orail siRNA or dominantnegative mutant Orai1 [57]. Exogenous wild-type Orail rescued the tube formation after Orail knock-down by siRNA [57]. Synta 66 inhibited endothelial cell migration and in vitro tube formation and suppressed angiogenesis in vivo in the chick chorioallantoic membrane [57]. Similarly, suppression of STIM1 inhibited angiogenesis in vivo [22]. A study of EA. hy926 cells, by contrast, found no effect of Orail siRNA on in vitro endothelial tube formation, a difference the authors suggest may have been due to the absence, or low concentration of, VEGF in their studies [5]. A reduction in EA.hy926 cell proliferation by Orail siRNA was observed [5], similar to findings in HUVECs [1]. Proliferation and tubulogenesis of endothelial colony forming cells in the presence of VEGF was inhibited by BTP-2 [30]. Overall, the findings suggest that Orail channels and SOCE are important in endothelial cell proliferation, VEGF signalling, VEGF-driven endothelial cell migration and VEGF-driven angiogenesis.

\section{Orai1 in thrombus and inflammation}

This review focuses on two dominant cell types of the vascular wall but it should be borne in mind that Orail is also expressed in blood cells (T cells, monocytes, platelets, etc.) which can interact with and integrate in the vascular wall as part of inflammatory and thrombotic events. Numerous studies suggest the importance of Orail channels in thrombus formation and inflammation [18, 32, 39].

\section{Orai2 and Orai3}

Orai2 and Orai3 mRNAs are also detected in vascular smooth muscle cells and endothelial cells [1, 8, 59, 80], showing either substantial abundances that are greater than those of Orail mRNA $[8,59]$ or minimal abundance [88].
Orai 2 and Orai 3 proteins have also been detected $[13,17$, 24, 77, 88]. Orai2 and Orai3 were up-regulated in proliferating compared with contractile vascular smooth muscle cells [8]. Knock-downs of Orai2, Orai3 or Orai2 and Orai3 by siRNAs have shown no effect on SOCE or basal cytosolic $\mathrm{Ca}^{2+}$ in proliferating vascular smooth muscle cells $[8$, $15,59,77]$ even though over-expression studies in the human embryonic kidney (HEK) 293 cell line have suggested that Orai2 or Orai3 is capable of reconstituting an I-CRAC [61]. There was also no effect of Orai2 or Orai3 siRNA on vascular smooth muscle cell migration or proliferation $[8,15]$. Intriguing studies of an endogenous arachidonate-regulated $\mathrm{Ca}^{2+}$ (ARC) channel in HEK 293 cells have suggested that this channel is formed from a pentameric arrangement of Orail with Orai3 [84]. It is not reported if such a channel is relevant to the vasculature.

\section{Conclusions and future challenges}

The evidence points to Orail as a novel $\mathrm{Ca}^{2+}$ channel of blood vessels. The strongest evidence for expression and roles of Orail in the vasculature is in remodelling events that relate to neointimal hyperplasia and angiogenesis. Orai1 can play significant positive roles in migrating and proliferating behaviours of vascular smooth muscle and endothelial cells, all of which are important in events such as neointimal hyperplasia and angiogenesis. There is less evidence for the expression and roles of Orail in the contractile state of blood vessels but function is indicated and may be important in specific vessels under certain conditions. In both the remodelling and contractile contexts, there is need for more information on the expression and functional relevance of endogenous Orail channels especially in freshly isolated cells and tissues and, in vivo, in animals under physiological and pathological conditions.

A fundamental implication from Orail's discovery is that it represents a long-sought, privileged and widespread mechanism for refilling of depleted $\mathrm{Ca}^{2+}$ stores. It would seem to be true that Orail provides such a mechanism, but strengths of the argument depend substantially on principles developed from studies of cell types other than vascular smooth muscle and endothelial cells or from overexpression approaches in cell lines. Reports on vascular smooth muscle cells and endothelial cells provide numerous indications that store depletion is associated with the activation or insertion not only of Orail channels but also additional types of $\mathrm{Ca}^{2+}$-permeable channel that impact on cytosolic $\mathrm{Ca}^{2+}$ concentrations directly or indirectly. The relationship between these channels and Orail requires further investigation and would benefit from the application of new technical approaches that provide better resolution in subcellular space, better information about associations 
between endogenous proteins in physiological cells and better information about activation of the channels in physiological and pathological contexts when $\mathrm{Ca}^{2+}$ signalling occurs in three-dimensional structures that are in slow turnover (quiescence) or actively remodelling.

An important step in the short term is to better address the relevance to physiological settings of experimentally induced store depletion events and the SOCE phenomenon. Several studies suggest that $\mathrm{Ca}^{2+}$ release is not necessarily associated with store depletion and thus that a refilling process may be activated and maintained in the absence of store depletion. The reported activation of Orail-dependent $\mathrm{Ca}^{2+}$ entry by PDGF or VEGF in the continuous presence of extracellular $\mathrm{Ca}^{2+}$ suggests the involvement of Orail in store refilling even when there is little or no store depletion. If there is indeed such efficient store refilling via Orail, it raises questions about the physiological activation mechanism of Orail and the appropriateness of considering Orail only in terms of the store depletion-activated Orai1-STIM1 I-CRAC complex. Dependence of non-selective cationic current on Orai1 [103] and the greater effect of Orail siRNA than Synta 66 on vascular smooth muscle cell migration [59] are suggestive of multiple rather than singular functions of Orail. What these other functions are and whether they arise indirectly through the I-CRAC mechanism remain to be determined.

One of the most obvious problems in the field is the apparently conflicting published data sets on the molecular basis of SOCE. Put simply: Is SOCE mediated by Orai1, TRPC, other channels, etc., or all of them? How can different investigators use apparently similar experimental protocols and end up with such widely differing results and conclusions (e.g. Orail explains all of SOCE and TRPC none, or vice versa)? It would be helpful if experimental conditions were standardised. Another way forward would be to decrease emphasis on the SOCE phenomenon and focus attention instead on physiological activators of the channels and studies in physiological conditions. A further way forward is to accept that multiple channel types can contribute to SOCE in cells in vitro in planar culture or suspension but that the physiological relevance of these contributions depends on the exact cell type and the context. An intriguing study, for example, suggested the importance of the TRPC4 channel at the point in time when endothelial cells make contact [43]. Such a subtle but important effect would variably contribute to in vitro planar cell culture studies depending on the confluence of the cells. Also important in such a situation would be the substrate on which the cells were grown and placed during experiments.

Additional challenges ahead involve addressing (1) whether the vascular I-CRAC channel has a distinct molecular component compared with the I-CRAC channel in T cells, conferring a basis for distinction by pharmacology and, potentially, therapeutic drugs; (2) the roles of Orai2 and Orai3 in blood vessels (e.g. Is an ARC channel relevant?); and (3) the nature of the down-stream pathways of Orail channels and other channel types contributing to SOCE (there may be, for example, discrete consequences of activating Orail-compared with TRPC1-containing channels [60]).

The discovery of Orail in T cells has led to an interesting and lively period of research in the $\mathrm{Ca}^{2+}$ signalling and vascular fields. A previously unrecognised channel type of vascular smooth muscle cells and endothelial cells seems to have been identified and appears to have important functional consequences that could be relevant and significant for fundamental understanding and new therapeutic strategies. We are, however, at the beginning of this period of investigation and there is much still to learn and resolve. Application of new experimental methods and emphasis on other types of existing methods will be necessary as the field progresses.

Acknowledgments J Li and S Tumova provided helpful comments. The laboratory has received funding for research on this topic from the Wellcome Trust, Medical Research Council, British Heart Foundation, Cancer Research UK, the Biotechnology and Biological Sciences Research Council and AstraZeneca.

Open Access This article is distributed under the terms of the Creative Commons Attribution License which permits any use, distribution, and reproduction in any medium, provided the original author(s) and the source are credited.

\section{References}

1. Abdullaev IF, Bisaillon JM, Potier M, Gonzalez JC, Motiani RK, Trebak M (2008) Stim1 and Orail mediate CRAC currents and storeoperated calcium entry important for endothelial cell proliferation. Circ Res 103(11):1289-1299

2. Abramowitz J, Birnbaumer L (2009) Physiology and pathophysiology of canonical transient receptor potential channels. FASEB J 23(2):297-328

3. Al-Shawaf E, Naylor J, Taylor H, Riches K, Milligan CJ, O'Regan D, Porter KE, Li J, Beech DJ (2010) Short-term stimulation of calcium-permeable transient receptor potential canonical 5-containing channels by oxidized phospholipids. Arterioscler Thromb Vasc Biol 30(7):1453-1459

4. AL-Shawaf E, Tumova S, Naylor J, Majeed Y, Li J, Beech DJ (2011) GVI phospholipase $\mathrm{A}_{2}$ role in the stimulatory effect of sphingosine-1phosphate on TRPC5 cationic channels. Cell Calcium 50(4):343-350

5. Antigny F, Girardin N, Frieden M (2011) TRPC channels are required for in vitro endothelial tube formation. J Biol Chem 287 (8):5917-5927. doi:10.1074/jbc.M111.295733

6. Antigny F, Jousset H, Konig S, Frieden M (2011) Thapsigargin activates $\mathrm{Ca}^{2+}$ entry both by store-dependent, STIM1/Orai1-mediated, and store-independent, TRPC3/PLC/PKC-mediated pathways in human endothelial cells. Cell Calcium 49(2):115-127

7. Aubart FC, Sassi Y, Coulombe A, Mougenot N, Vrignaud C, Leprince P, Lechat P, Lompre AM, Hulot JS (2009) RNA interference targeting STIM1 suppresses vascular smooth muscle cell 
proliferation and neointima formation in the rat. Mol Ther 17 (3):455-462

8. Baryshnikov SG, Pulina MV, Zulian A, Linde CI, Golovina VA (2009) Orai1, a critical component of store-operated $\mathrm{Ca}^{2+}$ entry, is functionally associated with $\mathrm{Na}^{+} / \mathrm{Ca}^{2+}$ exchanger and plasma membrane $\mathrm{Ca}^{2+}$ pump in proliferating human arterial myocytes. Am J Physiol Cell Physiol 297(5):C1103-1112

9. Beech DJ (2007) Ion channel switching and activation in smoothmuscle cells of occlusive vascular diseases. Biochem Soc Trans 35(Pt 5):890-894

10. Beech DJ, Bahnasi YM, Dedman AM, Al-Shawaf E (2009) TRPC channel lipid specificity and mechanisms of lipid regulation. Cell Calcium 45(6):583-588

11. Bergdahl A, Gomez MF, Dreja K, Xu SZ, Adner M, Beech DJ, Broman J, Hellstrand P, Sward K (2003) Cholesterol depletion impairs vascular reactivity to endothelin-1 by reducing storeoperated $\mathrm{Ca}^{2+}$ entry dependent on TRPC1. Circ Res 93(9):839847

12. Bergdahl A, Gomez MF, Wihlborg AK, Erlinge D, Eyjolfson A, Xu SZ, Beech DJ, Dreja K, Hellstrand P (2005) Plasticity of TRPC expression in arterial smooth muscle: correlation with store-operated $\mathrm{Ca}^{2+}$ entry. Am J Physiol Cell Physiol 288(4): C872-880

13. Berra-Romani R, Mazzocco-Spezzia A, Pulina MV, Golovina VA (2008) $\mathrm{Ca}^{2+}$ handling is altered when arterial myocytes progress from a contractile to a proliferative phenotype in culture. Am J Physiol Cell Physiol 295(3):C779-790

14. Bird GS, DeHaven WI, Smyth JT, Putney JW Jr (2008) Methods for studying store-operated calcium entry. Methods 46(3):204212

15. Bisaillon JM, Motiani RK, Gonzalez-Cobos JC, Potier M, Halligan KE, Alzawahra WF, Barroso M, Singer HA, Jourd'heuil D, Trebak M (2010) Essential role for STIM1/Orai1-mediated calcium influx in PDGF-induced smooth muscle migration. Am J Physiol Cell Physiol 298(5):C993-1005

16. Blair NT, Kaczmarek JS, Clapham DE (2009) Intracellular calcium strongly potentiates agonist-activated TRPC5 channels. J Gen Physiol 133(5):525-546

17. Bobe R, Hadri L, Lopez JJ, Sassi Y, Atassi F, Karakikes I, Liang L, Limon I, Lompre AM, Hatem SN, Hajjar RJ, Lipskaia L (2011) SERCA2a controls the mode of agonist-induced intracellular $\mathrm{Ca}^{2+}$ signal, transcription factor NFAT and proliferation in human vascular smooth muscle cells. J Mol Cell Cardiol 50 (4):621-633

18. Braun A, Varga-Szabo D, Kleinschnitz C, Pleines I, Bender M, Austinat M, Bosl M, Stoll G, Nieswandt B (2009) Orail (CRACM1) is the platelet SOC channel and essential for pathological thrombus formation. Blood 113(9):2056-2063

19. Brueggemann LI, Markun DR, Henderson KK, Cribbs LL, Byron KL (2006) Pharmacological and electrophysiological characterization of store-operated currents and capacitative $\mathrm{Ca}^{2+}$ entry in vascular smooth muscle cells. J Pharmacol Exp Ther 317(2):488499

20. Cahalan MD (2009) STIMulating store-operated $\mathrm{Ca}^{2+}$ entry. Nat Cell Biol 11(6):669-677

21. Casteels R, Droogmans G (1981) Exchange characteristics of the noradrenaline-sensitive calcium store in vascular smooth muscle cells or rabbit ear artery. J Physiol 317:263-279

22. Chen YF, Chiu WT, Chen YT, Lin PY, Huang HJ, Chou CY, Chang HC, Tang MJ, Shen MR (2011) Calcium store sensor stromalinteraction molecule 1-dependent signaling plays an important role in cervical cancer growth, migration, and angiogenesis. Proc Natl Acad Sci U S A 108(37):15225-15230

23. Cheong A, Li J, Sukumar P, Kumar B, Zeng F, Riches K, Munsch C, Wood IC, Porter KE, Beech DJ (2011) Potent suppression of vascular smooth muscle cell migration and human neointimal hyperplasia by $\mathrm{K}_{\mathrm{V}} 1.3$ channel blockers. Cardiovasc Res 89 (2):282-289

24. Chuang TY, Au LC, Wang LC, Ho LT, Yang DM, Juan CC (2012) Potential effect of resistin on the ET-1-increased reactions of blood pressure in rats and $\mathrm{Ca}^{2+}$ signaling in vascular smooth muscle cells. J Cell Physiol 227(4):1610-1618

25. Cidad P, Moreno-Dominguez A, Novensa L, Roque M, Barquin L, Heras M, Perez-Garcia MT, Lopez-Lopez JR (2010) Characterization of ion channels involved in the proliferative response of femoral artery smooth muscle cells. Arterioscler Thromb Vasc Biol 30(6):1203-1211

26. Di Sabatino A, Rovedatti L, Kaur R, Spencer JP, Brown JT, Morisset VD, Biancheri P, Leakey NA, Wilde JI, Scott L, Corazza GR, Lee K, Sengupta N, Knowles CH, Gunthorpe MJ, McLean PG, MacDonald TT, Kruidenier L (2009) Targeting gut T cell $\mathrm{Ca}^{2+}$ release-activated $\mathrm{Ca}^{2+}$ channels inhibits $\mathrm{T}$ cell cytokine production and T-box transcription factor T-bet in inflammatory bowel disease. J Immunol 183 (5):3454-3462

27. Dickhout JG, Carlisle RE, Austin RC (2011) Interrelationship between cardiac hypertrophy, heart failure, and chronic kidney disease: endoplasmic reticulum stress as a mediator of pathogenesis. Circ Res 108(5):629-642

28. Ding Y, Winters A, Ding M, Graham S, Akopova I, Muallem S, Wang Y, Hong JH, Gryczynski Z, Yang SH, Birnbaumer L, Ma R (2011) Reactive oxygen species-mediated TRPC6 protein activation in vascular myocytes, a mechanism for vasoconstrictorregulated vascular tone. J Biol Chem 286(36):31799-31809

29. Dominguez-Rodriguez A, Diaz I, Rodriguez-Moyano M, Calderon-Sanchez E, Rosado JA, Ordonez A, Smani T (2012) Urotensin-II signaling mechanism in rat coronary artery: role of STIM1 and Orail-dependent store operated calcium influx in vasoconstriction. Arterioscler Thromb Vasc Biol. doi:10.1161/ ATVBAHA.111.243014

30. Dragoni S, Laforenza U, Bonetti E, Lodola F, Bottino C, Berra-Romani R, Carlo Bongio G, Cinelli MP, Guerra G, Pedrazzoli P, Rosti V, Tanzi F, Moccia F (2011) Vascular endothelial growth factor stimulates endothelial colony forming cells proliferation and tubulogenesis by inducing oscillations in intracellular $\mathrm{Ca}^{2+}$ concentration. Stem Cells 29(11):1898-1907

31. Edwards JM, Neeb ZP, Alloosh MA, Long X, Bratz IN, Peller CR, Byrd JP, Kumar S, Obukhov AG, Sturek M (2010) Exercise training decreases store-operated $\mathrm{Ca}^{2+}$ entry associated with metabolic syndrome and coronary atherosclerosis. Cardiovasc Res 85 (3):631-640

32. Feske S (2009) ORAI1 and STIM1 deficiency in human and mice: roles of store-operated $\mathrm{Ca}^{2+}$ entry in the immune system and beyond. Immunol Rev 231(1):189-209

33. Feske S, Gwack Y, Prakriya M, Srikanth S, Puppel SH, Tanasa B, Hogan PG, Lewis RS, Daly M, Rao A (2006) A mutation in Orail causes immune deficiency by abrogating CRAC channel function. Nature 441(7090):179-185

34. Flemming R, Cheong A, Dedman AM, Beech DJ (2002) Discrete store-operated calcium influx into an intracellular compartment in rabbit arteriolar smooth muscle. J Physiol 543(Pt 2):455-464

35. Flemming R, Xu SZ, Beech DJ (2003) Pharmacological profile of store-operated channels in cerebral arteriolar smooth muscle cells. Br J Pharmacol 139(5):955-965

36. Freichel M, Suh SH, Pfeifer A, Schweig U, Trost C, Weissgerber P, Biel M, Philipp S, Freise D, Droogmans G, Hofmann F, Flockerzi V, Nilius B (2001) Lack of an endothelial storeoperated $\mathrm{Ca}^{2+}$ current impairs agonist-dependent vasorelaxation in TRP4-/- mice. Nat Cell Biol 3(2):121-127

37. Gericke M, Oike M, Droogmans G, Nilius B (1994) Inhibition of capacitative $\mathrm{Ca}^{2+}$ entry by a $\mathrm{Cl}^{-}$channel blocker in human endothelial cells. Eur J Pharmacol 269(3):381-384 
38. Giachini FR, Chiao CW, Carneiro FS, Lima VV, Carneiro ZN, Dorrance AM, Tostes RC, Webb RC (2009) Increased activation of stromal interaction molecule-1/Orai-1 in aorta from hypertensive rats: a novel insight into vascular dysfunction. Hypertension 53(2):409-416

39. Gilio K, van Kruchten R, Braun A, Berna-Erro A, Feijge MA, Stegner D, van der Meijden PE, Kuijpers MJ, Varga-Szabo D, Heemskerk JW, Nieswandt B (2010) Roles of platelet STIM1 and Orai1 in glycoprotein VI- and thrombin-dependent procoagulant activity and thrombus formation. J Biol Chem 285(31):2362923638

40. Girardin NC, Antigny F, Frieden M (2010) Electrophysiological characterization of store-operated and agonist-induced $\mathrm{Ca}^{2+}$ entry pathways in endothelial cells. Pflugers Arch 460(1):109-120

41. Golovina VA (1999) Cell proliferation is associated with enhanced capacitative $\mathrm{Ca}^{2+}$ entry in human arterial myocytes. Am J Physiol 277(2 Pt 1):C343-349

42. Golovina VA, Platoshyn O, Bailey CL, Wang J, Limsuwan A, Sweeney M, Rubin LJ, Yuan JX (2001) Upregulated TRP and enhanced capacitative $\mathrm{Ca}^{2+}$ entry in human pulmonary artery myocytes during proliferation. Am J Physiol Heart Circ Physiol 280(2):H746-755

43. Graziani A, Poteser M, Heupel WM, Schleifer H, Krenn M, Drenckhahn D, Romanin C, Baumgartner W, Groschner K (2010) Cell-cell contact formation governs $\mathrm{Ca}^{2+}$ signaling by TRPC4 in the vascular endothelium: evidence for a regulatory TRPC4-beta-catenin interaction. J Biol Chem 285(6):4213-4223

44. Grigoriev I, Gouveia SM, van der Vaart B, Demmers J, Smyth JT, Honnappa S, Splinter D, Steinmetz MO, Putney JW Jr, Hoogenraad CC, Akhmanova A (2008) STIM1 is a MT-plus-end-tracking protein involved in remodeling of the ER. Curr Biol 18(3):177-182

45. Guo RW, Wang H, Gao P, Li MQ, Zeng CY, Yu Y, Chen JF, Song MB, Shi YK, Huang L (2009) An essential role for stromal interaction molecule 1 in neointima formation following arterial injury. Cardiovasc Res 81(4):660-668

46. Guo RW, Yang LX, Li MQ, Pan XH, Liu B, Deng YL (2012) Stim1- and Orai1-mediated store-operated calcium entry is critical for angiotensin II-induced vascular smooth muscle cell proliferation. Cardiovasc Res 93(2):360-370. doi:10.1093/cvr/ cvr307

47. Gwack Y, Srikanth S, Oh-Hora M, Hogan PG, Lamperti ED, Yamashita M, Gelinas C, Neems DS, Sasaki Y, Feske S, Prakriya M, Rajewsky K, Rao A (2008) Hair loss and defective T- and Bcell function in mice lacking ORAI1. Mol Cell Biol 28(17):52095222

48. Hannon GJ, Rossi JJ (2004) Unlocking the potential of the human genome with RNA interference. Nature 431(7006):371-378

49. Hauser CT, Tsien RY (2007) A hexahistidine- $\mathrm{Zn}^{2+}$-dye label reveals STIM1 surface exposure. Proc Natl Acad Sci U S A 104(10):3693-3697

50. Hopson KP, Truelove J, Chun J, Wang Y, Waeber C (2011) S1P activates store-operated calcium entry via receptor- and nonreceptor-mediated pathways in vascular smooth muscle cells. Am J Physiol Cell Physiol 300(4):C919-926

51. Hui H, McHugh D, Hannan M, Zeng F, Xu SZ, Khan SU, Levenson R, Beech DJ, Weiss JL (2006) Calcium-sensing mechanism in TRPC5 channels contributing to retardation of neurite outgrowth. J Physiol 572(Pt 1):165-172

52. Jain RK (2003) Molecular regulation of vessel maturation. Nat Med 9(6):685-693

53. Koslowski M, Sahin U, Dhaene K, Huber C, Tureci O (2008) MS4A12 is a colon-selective store-operated calcium channel promoting malignant cell processes. Cancer Res 68(9):34583466

54. Krapivinsky G, Krapivinsky L, Stotz SC, Manasian Y, Clapham DE (2011) POST, partner of stromal interaction molecule 1
(STIM1), targets STIM1 to multiple transporters. Proc Natl Acad Sci U S A 108(48):19234-19239

55. Kumar B, Dreja K, Shah SS, Cheong A, Xu SZ, Sukumar P, Naylor J, Forte A, Cipollaro M, McHugh D, Kingston PA, Heagerty AM, Munsch CM, Bergdahl A, Hultgardh-Nilsson A, Gomez MF, Porter KE, Hellstrand P, Beech DJ (2006) Upregulated TRPC1 channel in vascular injury in vivo and its role in human neointimal hyperplasia. Circ Res 98(4):557-563

56. Lei X, Zhang S, Emani B, Barbour SE, Ramanadham S (2010) A link between endoplasmic reticulum stress-induced beta-cell apoptosis and the group VIA $\mathrm{Ca}^{2+}$-independent phospholipase $\mathrm{A}_{2}$ (iPLA2 $\beta$ ). Diabetes Obes Metab 12(Suppl 2):93-98

57. Li J, Cubbon RM, Wilson LA, Amer MS, McKeown L, Hou B, Majeed Y, Tumova S, Seymour VA, Taylor H, Stacey M, O'Regan D, Foster R, Porter KE, Kearney MT, Beech DJ (2011) Orai1 and CRAC channel dependence of VEGFactivated $\mathrm{Ca}^{2+}$ entry and endothelial tube formation. Circ Res 108(10):1190-1198

58. Li J, McKeown L, Milligan CJ, Naylor J, O'Regan D, Porter KE, Beech DJ (2009) Non-selective cationic current associated with ADAR1-edited human Orai1. 36th Congress of the International Union of Physiological Sciences: P3PM-20-14

59. Li J, McKeown L, Ojelabi O, Stacey M, Foster R, O'Regan D, Porter KE, Beech DJ (2011) Nanomolar potency and selectivity of a $\mathrm{Ca}^{2+}$ release-activated $\mathrm{Ca}^{2+}$ channel inhibitor against storeoperated $\mathrm{Ca}^{2+}$ entry and migration of vascular smooth muscle cells. Br J Pharmacol 164(2):382-393

60. Li J, Sukumar P, Milligan CJ, Kumar B, Ma ZY, Munsch CM, Jiang LH, Porter KE, Beech DJ (2008) Interactions, functions, and independence of plasma membrane STIM1 and TRPC1 in vascular smooth muscle cells. Circ Res 103(8): e97-104

61. Lis A, Peinelt C, Beck A, Parvez S, Monteilh-Zoller M, Fleig A, Penner R (2007) CRACM1, CRACM2, and CRACM3 are storeoperated $\mathrm{Ca}^{2+}$ channels with distinct functional properties. Curr Biol 17(9):794-800

62. Lu W, Wang J, Peng G, Shimoda LA, Sylvester JT (2009) Knockdown of stromal interaction molecule 1 attenuates storeoperated $\mathrm{Ca}^{2+}$ entry and $\mathrm{Ca}^{2+}$ responses to acute hypoxia in pulmonary arterial smooth muscle. Am J Physiol Lung Cell Mol Physiol 297(1):L17-25

63. Ma X, Cao J, Luo J, Nilius B, Huang Y, Ambudkar IS, Yao X (2010) Depletion of intracellular $\mathrm{Ca}^{2+}$ stores stimulates the translocation of vanilloid transient receptor potential 4-C1 heteromeric channels to the plasma membrane. Arterioscler Thromb Vasc Biol 30(11):2249-2255

64. Ma X, Cheng KT, Wong CO, O'Neil RG, Birnbaumer L, Ambudkar IS, Yao X (2011) Heteromeric TRPV4-C1 channels contribute to store-operated $\mathrm{Ca}^{2+}$ entry in vascular endothelial cells. Cell Calcium 50(6):502-509

65. Malli R, Naghdi S, Romanin C, Graier WF (2008) Cytosolic $\mathrm{Ca}^{2+}$ prevents the subplasmalemmal clustering of STIM1: an intrinsic mechanism to avoid $\mathrm{Ca}^{2+}$ overload. J Cell Sci 121(Pt 19):31333139

66. Maruyama Y, Ogura T, Mio K, Kato K, Kaneko T, Kiyonaka S, Mori Y, Sato C (2009) Tetrameric Orail is a teardrop-shaped molecule with a long, tapered cytoplasmic domain. J Biol Chem 284(20):13676-13685

67. Munoz E, Valero RA, Quintana A, Hoth M, Nunez L, Villalobos C (2011) Nonsteroidal anti-inflammatory drugs inhibit vascular smooth muscle cell proliferation by enabling the $\mathrm{Ca}^{2+}$-dependent inactivation of calcium release-activated calcium/orai channels normally prevented by mitochondria. J Biol Chem 286(18):1618616196

68. Naylor J, Al-Shawaf E, McKeown L, Manna PT, Porter KE, O'Regan D, Muraki K, Beech DJ (2011) TRPC5 channel sensitivities to 
antioxidants and hydroxylated stilbenes. J Biol Chem 286(7):50785086

69. Ng LC, McCormack MD, Airey JA, Singer CA, Keller PS, Shen XM, Hume JR (2009) TRPC1 and STIM1 mediate capacitative $\mathrm{Ca}^{2+}$ entry in mouse pulmonary arterial smooth muscle cells. $\mathrm{J}$ Physiol 587(Pt 11):2429-2442

70. Ng LC, Ramduny D, Airey JA, Singer CA, Keller PS, Shen XM, Tian H, Valencik M, Hume JR (2010) Orail interacts with STIM1 and mediates capacitative $\mathrm{Ca}^{2+}$ entry in mouse pulmonary arterial smooth muscle cells. Am J Physiol Cell Physiol 299(5):C10791090

71. Ng SW, di Capite J, Singaravelu K, Parekh AB (2008) Sustained activation of the tyrosine kinase Syk by antigen in mast cells requires local $\mathrm{Ca}^{2+}$ influx through $\mathrm{Ca}^{2+}$ release-activated $\mathrm{Ca}^{2+}$ channels. J Biol Chem 283(46):31348-31355

72. Ogawa A, Firth AL, Smith KA, Maliakal MV, Yuan JX (2012) PDGF enhances store-operated $\mathrm{Ca}^{2+}$ entry by upregulating STIM1/Orai1 via activation of Akt/mTOR in human pulmonary arterial smooth muscle cells. Am J Physiol Cell Physiol 302(2): C405-411

73. Olsson AK, Dimberg A, Kreuger J, Claesson-Welsh L (2006) VEGF receptor signalling - in control of vascular function. Nat Rev Mol Cell Biol 7(5):359-371

74. Ordaz B, Tang J, Xiao R, Salgado A, Sampieri A, Zhu MX, Vaca L (2005) Calmodulin and calcium interplay in the modulation of TRPC5 channel activity. Identification of a novel C-terminal domain for calcium/calmodulin-mediated facilitation. J Biol Chem 280(35):30788-30796

75. Parekh AB (2010) Store-operated CRAC channels: function in health and disease. Nat Rev Drug Discov 9(5):399-410

76. Park CY, Hoover PJ, Mullins FM, Bachhawat P, Covington ED, Raunser S, Walz T, Garcia KC, Dolmetsch RE, Lewis RS (2009) STIM1 clusters and activates CRAC channels via direct binding of a cytosolic domain to Orail. Cell 136(5):876-890

77. Potier M, Gonzalez JC, Motiani RK, Abdullaev IF, Bisaillon JM, Singer HA, Trebak M (2009) Evidence for STIM1- and Orai1dependent store-operated calcium influx through ICRAC in vascular smooth muscle cells: role in proliferation and migration. FASEB J 23(8):2425-2437

78. Roos J, DiGregorio PJ, Yeromin AV, Ohlsen K, Lioudyno M, Zhang S, Safrina O, Kozak JA, Wagner SL, Cahalan MD, Velicelebi G, Stauderman KA (2005) STIM1, an essential and conserved component of store-operated $\mathrm{Ca}^{2+}$ channel function. J Cell Biol 169(3):435-445

79. Saleh SN, Albert AP, Peppiatt-Wildman CM, Large WA (2008) Diverse properties of store-operated TRPC channels activated by protein kinase C in vascular myocytes. J Physiol 586(10):24632476

80. Sanchez-Hernandez Y, Laforenza U, Bonetti E, Fontana J, Dragoni S, Russo M, Avelino-Cruz JE, Schinelli S, Testa D, Guerra G, Rosti V, Tanzi F, Moccia F (2010) Store-operated $\mathrm{Ca}^{2+}$ entry is expressed in human endothelial progenitor cells. Stem Cells Dev 19(12):19671981

81. Sayner SL, Balczon R, Frank DW, Cooper DM, Stevens T (2011) Filamin $\mathrm{A}$ is a phosphorylation target of membrane but not cytosolic adenylyl cyclase activity. Am J Physiol Lung Cell Mol Physiol 301(1):L117-124

82. Shi J, Ju M, Abramowitz J, Large WA, Birnbaumer L, Albert AP (2012) TRPC1 proteins confer PKC and phosphoinositol activation on native heteromeric TRPC1/C5 channels in vascular smooth muscle: comparative study of wild-type and TRPC1-/mice. FASEB J 26(1):409-419

83. Shi J, Mori E, Mori Y, Mori M, Li J, Ito Y, Inoue R (2004) Multiple regulation by calcium of murine homologues of transient receptor potential proteins TRPC6 and TRPC7 expressed in HEK293 cells. J Physiol 561(Pt 2):415-432
84. Shuttleworth TJ (2009) Arachidonic acid, ARC channels, and Orai proteins. Cell Calcium 45(6):602-610

85. Smani T, Zakharov SI, Csutora P, Leno E, Trepakova ES, Bolotina VM (2004) A novel mechanism for the store-operated calcium influx pathway. Nat Cell Biol 6(2):113-120

86. Stiber J, Hawkins A, Zhang ZS, Wang S, Burch J, Graham V, Ward CC, Seth M, Finch E, Malouf N, Williams RS, Eu JP, Rosenberg P (2008) STIM1 signalling controls storeoperated calcium entry required for development and contractile function in skeletal muscle. Nat Cell Biol 10(6):688697

87. Su Z, Guo X, Barker DS, Shoemaker RL, Marchase RB, Blalock JE (2005) A store-operated nonselective cation channel in human lymphocytes. Cell Mol Neurobiol 25(3-4):625647

88. Sundivakkam PC, Freichel M, Singh V, Yuan JP, Vogel SM, Flockerzi V, Malik AB, Tiruppathi C (2012) The $\mathrm{Ca}^{2+}$ sensor STIM1 is necessary and sufficient for the store-operated $\mathrm{Ca}^{2+}$ entry function of TRPCs in endothelial cells. Mol Pharmacol. doi:10.1124/ mol.111.074658

89. Sweeney M, Yu Y, Platoshyn O, Zhang S, McDaniel SS, Yuan JX (2002) Inhibition of endogenous TRP1 decreases capacitative $\mathrm{Ca}^{2+}$ entry and attenuates pulmonary artery smooth muscle cell proliferation. Am J Physiol Lung Cell Mol Physiol 283(1):L144155

90. Tai K, Hamaide MC, Debaix H, Gailly P, Wibo M, Morel N (2008) Agonist-evoked calcium entry in vascular smooth muscle cells requires $\mathrm{IP}_{3}$ receptor-mediated activation of TRPC1. Eur J Pharmacol 583(1):135-147

91. Takahashi Y, Watanabe H, Murakami M, Ohba T, Radovanovic M, Ono K, Iijima T, Ito H (2007) Involvement of transient receptor potential canonical 1 (TRPC1) in angiotensin IIinduced vascular smooth muscle cell hypertrophy. Atherosclerosis 195(2):287-296

92. Takahashi Y, Watanabe H, Murakami M, Ono K, Munehisa Y, Koyama T, Nobori K, Iijima T, Ito H (2007) Functional role of stromal interaction molecule 1 (STIM1) in vascular smooth muscle cells. Biochem Biophys Res Commun 361 (4):934-940

93. Tiruppathi C, Freichel M, Vogel SM, Paria BC, Mehta D, Flockerzi $\mathrm{V}$, Malik AB (2002) Impairment of store-operated $\mathrm{Ca}^{2+}$ entry in TRPC4(-/-) mice interferes with increase in lung microvascular permeability. Circ Res 91(1):70-76

94. Trepakova ES, Gericke M, Hirakawa Y, Weisbrod RM, Cohen RA, Bolotina VM (2001) Properties of a native cation channel activated by $\mathrm{Ca}^{2+}$ store depletion in vascular smooth muscle cells. J Biol Chem 276(11):7782-7790

95. Vaca L (2010) SOCIC: the store-operated calcium influx complex. Cell Calcium 47(3):199-209

96. Vig M, DeHaven WI, Bird GS, Billingsley JM, Wang H, Rao PE, Hutchings AB, Jouvin MH, Putney JW, Kinet JP (2008) Defective mast cell effector functions in mice lacking the CRACM1 pore subunit of store-operated calcium release-activated calcium channels. Nat Immunol 9(1):89-96

97. Vig M, Peinelt C, Beck A, Koomoa DL, Rabah D, KoblanHuberson M, Kraft S, Turner H, Fleig A, Penner R, Kinet JP (2006) CRACM1 is a plasma membrane protein essential for store-operated $\mathrm{Ca}^{2+}$ entry. Science 312(5777):1220-1223

98. Wang Y, Deng X, Mancarella S, Hendron E, Eguchi S, Soboloff J, Tang XD, Gill DL (2010) The calcium store sensor, STIM1, reciprocally controls Orai and $\mathrm{Ca}_{\mathrm{V}} 1.2$ channels. Science 330 (6000):105-109

99. Wissenbach U, Philipp SE, Gross SA, Cavalie A, Flockerzi V (2007) Primary structure, chromosomal localization and expression in immune cells of the murine ORAI and STIM genes. Cell Calcium 42(4-5):439-446 
100. Xu SZ, Beech DJ (2001) TrpC1 is a membrane-spanning subunit of store-operated $\mathrm{Ca}^{2+}$ channels in native vascular smooth muscle cells. Circ Res 88(1):84-87

101. Xu SZ, Boulay G, Flemming R, Beech DJ (2006) E3-targeted anti-TRPC5 antibody inhibits store-operated calcium entry in freshly isolated pial arterioles. Am J Physiol Heart Circ Physiol 291(6):H2653-2659

102. Xu SZ, Sukumar P, Zeng F, Li J, Jairaman A, English A, Naylor J, Ciurtin C, Majeed Y, Milligan CJ, Bahnasi YM, Al-Shawaf E, Porter KE, Jiang LH, Emery P, Sivaprasadarao A, Beech DJ (2008) TRPC channel activation by extracellular thioredoxin. Nature 451(7174):69-72

103. Yang B, Gwozdz T, Dutko-Gwozdz J, Bolotina VM (2012) Orai1 and $\mathrm{Ca}^{2+}$-independent phospholipase $\mathrm{A}_{2}$ are required for storeoperated IcatSOC current, $\mathrm{Ca}^{2+}$ entry and proliferation of primary vascular smooth muscle cell. Am J Physiol Cell Physiol. doi:10.1152/ajpcell.00312.2011

104. Yuan JP, Zeng W, Dorwart MR, Choi YJ, Worley PF, Muallem S (2009) SOAR and the polybasic STIM1 domains gate and regulate Orai channels. Nat Cell Biol 11(3):337-343
105. Zakharov SI, Smani T, Dobrydneva Y, Monje F, Fichandler C, Blackmore PF, Bolotina VM (2004) Diethylstilbestrol is a potent inhibitor of store-operated channels and capacitative $\mathrm{Ca}^{2+}$ influx. Mol Pharmacol 66(3):702-707

106. Zeng W, Yuan JP, Kim MS, Choi YJ, Huang GN, Worley PF, Muallem S (2008) STIM1 gates TRPC channels, but not Orai1, by electrostatic interaction. Mol Cell 32(3):439448

107. Zhang W, Halligan KE, Zhang X, Bisaillon JM, Gonzalez-Cobos JC, Motiani RK, Hu G, Vincent PA, Zhou J, Barroso M, Singer HA, Matrougui K, Trebak M (2011) Orai1-mediated I (CRAC) is essential for neointima formation after vascular injury. Circ Res 109(5):534-542

108. Zhou Y, Meraner P, Kwon HT, Machnes D, Oh-hora M, Zimmer J, Huang Y, Stura A, Rao A, Hogan PG (2010) STIM1 gates the store-operated calcium channel ORAI1 in vitro. Nat Struct Mol Biol 17(1):112-116

109. Zhou Y, Ramachandran S, Oh-Hora M, Rao A, Hogan PG (2010) Pore architecture of the ORAI1 store-operated calcium channel. Proc Natl Acad Sci U S A 107(11):4896-4901 